\title{
The Economic Cost of the American Civil War: Estimates and Implications
}

\section{Citation}

Goldin, Claudia D. and Frank D. Lewis. 1975. The economic cost of the American Civil War: Estimates and implications. Journal of Economic History 35(2): 299-326.

\section{Published Version}

http://www.jstor.org/stable/2119410

\section{Permanent link}

http://nrs.harvard.edu/urn-3:HUL.InstRepos:2662305

\section{Terms of Use}

This article was downloaded from Harvard University's DASH repository, and is made available under the terms and conditions applicable to Other Posted Material, as set forth at http:// nrs.harvard.edu/urn-3:HUL.InstRepos:dash.current.terms-of-use\#LAA

\section{Share Your Story}

The Harvard community has made this article openly available.

Please share how this access benefits you. Submit a story.

\section{Accessibility}




\section{THE JOURNAL OF ECONOMIC HISTORY}

VOLUME XXXV

JUNE 1975

NUMBER 2

\section{The Economic Cost of the American Civil War: Estimates and Implications}

We are right to see power, prestige, and confidence as conditioned by the Civil War. But it is a very easy step to regard the War, therefore, as a jolly piece of luck only slightly disguised, part of our divinely instituted success story, and to think, in some shadowy corner of the mind, of the dead at Gettysburg as a small price to pay for the development of a really satisfactory and cheap compact car with decent pick-up and road-holding capability. It is to our credit that we survived the War and tempered our national fiber in the process, but human decency and the future security of our country demand that we look at the costs. What are some of the costs? Robert Penn Warren, The Legacy of the Civil War (New York: Random House, 1961), pp. 49-50.

\section{INTRODUCTION}

7 HE economic impact of the American Civil War has received a 1 prominent place in historical literature. It has been extensively debated since the publication of the controversial works of Louis Hacker and Charles and Mary Beard. The effects of the war on industrialization and income distribution have been discussed in a long series of articles among which those of Cochran, Salsbury, and Engerman are best known. ${ }^{1}$ The debate has been comprehensive,

We would like to thank Stanley Engerman, Hugh Rockoff, Richard Sutch, and three referees for their helpful comments.

1 See Thomas C. Cochran, "Did the Civil War Retard Industrialization?" Mississippi Valley Historical Review, XLVIII (September 1961), 197-210; Stanley Engerman, "The Economic Impact of the Civil War," Explorations in Entrepreneurial History, Second Series, III (Spring-Summer 1966), 176-199; Stephen Salsbury, "The Effect of the Civil War on American Industrial Development," in Ralph Andreano, editor, The Economic Impact of the American Civil War (New York: Schenkman Publishing Co., 1967). The Cochran and Engerman articles are also reprinted in 
but unfortunately one is still unable to draw firm conclusions from the present data concerning crucial issues. Although it is now known that the war's immediate impact was not expansionary, its long range effects are still unclear.

We hope that this article will help to resolve some of the broader issues concerning the economic effects of the war. Although this work does not answer completely the questions raised by the classic studies in this field, it does provide data which should be helpful in unriddling some of them.

The initial sections of this article contain estimates of the cost of the American Civil War to the Union and the Confederacy. These cost estimates are of two types, direct and indirect. The direct measure is computed by adding up the actual war expenditures of both sides. We discuss the limitations of this procedure and introduce an indirect estimate which avoids most of the shortcomings of the previous method. This indirect estimate is computed under the assumption that a particular consumption stream would have existed in the absence of the conflict. The discounted difference between this consumption stream and that actually achieved constitutes the indirect measure of the cost of the war. The final sections of the paper use these estimates to resolve various economic issues involving the total and distributive effects of the war. These sections are meant to be suggestive of future research and are not intended to be exhaustive.

The cost of any war is difficult to measure. As John Maurice Clark wrote in his preface to The Costs of the World War to the American People, "[a] study of war costs is either a relatively simple matter of tabulation and fiscal allocation; or else it is an economic problem of insoluble difficulty." When a war involves an economy only to the extent of providing men and machines this accounting procedure, as Clark suggests, is easy and appropriate. But when the war also involves the destruction of productive capital, political instability and changes in the composition of the labor force, complications abound. Further problems can be added if the victor extracts a reparation at the end of the conflict.

the Andreano volume. See also Harry N. Scheiber, "Economic Change in the Civil War Era: An Analysis of Recent Studies," Civil War History, II (December 1965), for a summary of these and other papers.

2 John Maurice Clark, The Costs of the World War to the American People (New Haven: Yale University Press, 1931), p. xi. 
A computation of the cost of the American Civil War involves all of these complications. The mere adding up of expenditures on the war effort and the yalue of destroyed physical and human capital does not equal the total cost of the conflict, for it neglects the costs of instability, commercial stoppage and other economic factors. ${ }^{3}$ Furthermore, Louis Hacker and Charles and Mary Beard have suggested social and political reasons for doubting that this summation equals the net cost. ${ }^{4}$

Although the cost of the American Civil War is referred to in many studies, no systematic computation has been made of it. Even a recent volume of essays on the economic impact of the Civil War does not include an estimate. ${ }^{5}$ Despite the fact that no complete study of Civil War costs has been made, several researchers have suggested the extent to which the war drained the economy during its four years. However, these studies have equated war costs with the totality of military expenditures and capital destruction and have thereby omitted both possible additional costs and benefits. ${ }^{6}$

Some researchers who have studied these war costs have neglected human casualties, although for many purposes these costs should be included. There are several methods of estimating the loss of human

3 On the issue of commercial stoppage see R. A. Kessel and A. A. Alchian, "Real Wages in the North During the Civil War: Mitchell's Data Reinterpreted," reprinted in Andreano, The Economic Impact of the American Civil War.

4 Charles and Mary Beard interpret the Civil War as enabling the North through victory to achieve greater economic progress. The Beards state, "The Second American Revolution, while destroying the economic foundation of the slaveowning aristocracy, assured the triumph of business enterprise. . . . In 1860, just a little more than a billion dollars was invested in manufacturing and only 1,500,000 industrial wage earners were employed in the United States. In less than fifty years the capital had risen to more than twelve billion and the number of wage earners to $5,500,000 . \ldots$. ." (See The Rise of American Civilization [New York: Macmillan Co., 1927], II, pp. 166-192.) Louis M. Hacker repeated the same theme. "From about 1843 on, this process [the conversion of mercantile capitalism into industrial capitalism] visibly began to take place, stopping short of complete fulfillment because the rising industrial-capitalist class was not in possession of the instrumentalities of political power. In short, industrial capitalism, it became apparent by the late 1850's, was incapable of achieving full maturity unless it had control of the state. In these terms we are to read the meaning of the Civil War; for that conflict was a revolution in the sense that it represented a desperate struggle for political power between two classes each of which required control of the state to underwrite its own economic and social programs." (See The Triumph of American Capitalism [New York: Columbia University Press, 1940], p. 200.)

5 Andreano, The Economic Impact of the American Civil War.

6 For example, see Fred Shannon, America's Economic Growth (3rd ed.; New York: Macmillan Co., 1951), pp. 325-326. Shannon complicates matters even further by not discounting, by not deflating, and by counting the emancipation of slaves as a real social loss. 
life. Using a human capital approach, a summation of both the foregone earnings of those who died and the difference between actual and hypothetical earnings of those who were wounded can be a fair approximation of these costs. It is important to note that the method of evaluating war deaths and war wounds depends critically on how the war cost estimate is to be applied. A human capital approach appears justified if one wants to know the extent to which gross national product or some other measure of economic activity was reduced as a consequence of the war. But if one is considering the losses experienced by those who survived the war, inclusion of the full marginal products of those who did not would be unjustified.

In the empirical analysis which follows, the simple method of calculating war costs, involving the summation of all war-related expenditures and losses, is termed the "direct" estimate. In our calculations this statistic includes all Union and Confederate war expenditures, and human and physical capital destroyed in military actions. But because the estimate produced by this simple addition is incomplete we have constructed an "indirect" measure. We have created for this purpose a hypothetical North and South ${ }^{7}$ which did not fight a war during the years 1861 to 1865 . The consumption stream of persons in the warless economy is compared to that actually achieved with the war. The discounted value of the difference between these two streams represents the net costs (or possibly net benefits) of the war.

The indirect cost of the war has been calculated two ways. In one calculation, called the indirect cost to the "native" population, we compute the cost of the war to those persons living in the U.S. in 1861 and to their descendants. Therefore, we have not considered in this estimate that portion of the war's economic impact passed on to those who emigrated after 1861. This variant is important, for example, in interpreting political decisions made in 1861 .

A second indirect computation yielded the total net cost of the war to all persons in the United States. It therefore also includes the cost of the war to those who entered the U.S. after 1861. The difference between this indirect and the direct estimate represents the cost of all items which could not be computed directly. For

7 We equate the Union with the North and the Confederacy with the South merely for literary purposes. 
example, if computed for the Union this measure would include any redistributive gains from political victory.

THE DIRECT COST OF THE CIVIL WAR

\section{General Method}

The direct estimate of the cost of the war, as we have noted, includes all war expenditures by both Union and Confederate governments (including state and local outlays), and the value of destroyed human and physical capital. In only a limited way are the losses due to the disruptive effects of the war included in this calculation, and any gross benefits from the war are not incorporated. ${ }^{8}$

The direct cost of the war for the North is simpler to calculate than for the South. The records of the Union government are more complete and more accurate than those of the Confederacy. Even more important, the destruction of physical capital was almost wholly concentrated in the South.

\section{The Direct Cost of the Civil War to the North}

The components of our direct estimate for the North are given in Table 1. Because supporting materials for this calculation and many

8 The direct cost of the war can be represented graphically using the familiar production possibilities frontier where the axes include both present and future consumption of the outputs guns and butter. The distance $A B$ in the figure below represents all expenditures on war machinery. $\mathrm{CE}$ is the direct measure of the cost of

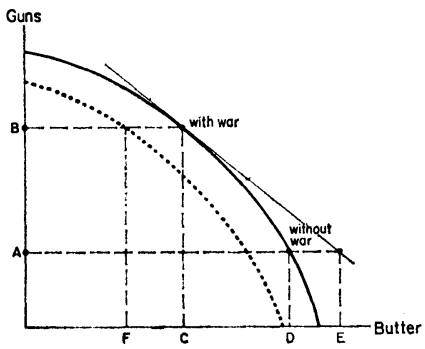

the war, but since it is evaluated at the current price ratio, the true cost is overstated by $\mathrm{DE}$. However, since annual expenditures were a minor fraction of total product (about 10 to 20 percent of GNP for both North and South) DE can be considered negligible. This follows because the marginal cost curve of guns probably had a very high elasticity. The direct cost estimate also may exceed actual foregone consumption because the war may have generated an increase in work effort shifting the production possibilities curve outward. We have not considered this point in our analysis. The destruction of human and physical capital shifts the production possibilities frontier inward, say to the dotted curve in the diagram. The distance FC represents additional foregone future consumption of butter due to the loss of productive capital. The total direct cost of the war is the sum of CD and FC. 


\section{TABLE 1 \\ DIRECT COST OF THE CIVIL WAR TO THE NORTHa \\ (Thousands, 1860 \$)}

(1) Expenditure by the Federal Governmentb

(2) Expenditure by State and Local Governments

$\$ 1,805,597$

485,673

(3) Additional Cost Due to the Draft ${ }^{d}$

11,035

(4) Human Capital Loss:

(a) Killede

954,922

(b) Woundede

364,734

(5) Less: Risk Premiums in Soldiers' Wage Billsg

(6) Total Direct Cost to the North

$\$ 3,365,846$

a All values are discounted at 6 percent to June 30,1861 . We justify this rate on the grounds that nonrisky interest rates during the period 1861 to 1909 averaged about 6 percent. See Table XV of supporting documents available upon request from either author. This set of tables will be referred to as "Notes." The Warren-Pearson wholesale price index, with minor adjustments, has been used as the deflator. See Table I of "Notes."

b This figure excludes military costs which would have been incurred without a war and includes the cost of demobilization. See Tables II-VI of "Notes."

c We have assumed for the purposes of discounting and deflating that the expenditures by state and local governments were distributed over time as that of the federal government. This figure also includes state and local bounties. See Tables VII and VIII of "Notes."

d This cost was in addition to military payment by the federal government due to the purchasing of substitutes and the draft. For example, if a substitute was paid $\$ 150$ by someone who had been drafted, a real war cost would not be included in federal expenditures. We have chosen $\$ 150$ as an average substitute payment because Shannon reports that "Philadelphia was filled with candidates from other states offering themselves as substitutes to the highest bidder. Some were said to have sold as low as $\$ 50$ and $\$ 150$ was a moderate price. When a few sold at $\$ 250$ the price, considering the condition of the market, was thought to be exorbitant." (Shannon, The Organization and Administration of the Union Army, 1861-1865, p. 61.) The number of men who were drafted and served or who were drafted and supplied a substitute was 162,535 (Kriedberg and Henry, History of Military Mobilization, p. 113). Drafting of soldiers was used in July 1863, and March, July, and December of 1864 . We use $\$ 150$ (current) as the average per man cost either for being drafted or for procuring a substitute. See Table IX of "Notes."

e The cost resulting from Civil War deaths is taken as the expected wage rate of those killed multiplied by the number who would have survived to a given year, summed over all years. The hypothetical earnings used for those actually killed are computed from weighted averages of actual farm and non-farm wages for the postwar period. This is justified because the number of persons expected to have been working in 1879 had the war not occurred is only $4.3 \%$ greater than the actual workforce, and it is only $2.8 \%$ greater for 1880 . See Tables X and XI of "Notes."

$f$ The number of Union soldiers wounded has been estimated at 275,175 (Randall and Donald, The Civil War and Reconstruction, p. 531). We assume there was an average loss of one-half potential earning capacity from these wounds.

g Including the value of human capital destruction in the total direct cost would constitute double counting if soldiers received higher pay as risk premiums. A comparison of civilian and military wage rates indicates that this additional compensation was slight. We infer either that soldiers underestimated the probabilities of death and injury or that patriotic duty was a sufficient incentive. The estimate presented above is the difference between military and civilian earnings, where military wages include costs transferred to drafted soldiers. The Union army and navy strength is given by Kendrick as: 


$\begin{array}{lr}1861 & \mathbf{5 5 , 6 0 0} \\ \mathbf{1 8 6 2} & 537,400 \\ 1863 & 924,300 \\ 1864 & 913,600 \\ 1865 & 961,600\end{array}$

Kendrick cites F. B. Heitman, Historical Register and Dictionary of the U.S. Army from its Organization, September 29, 1789 to March 2, 1903, Vol. II (Washington, D.C.: U.S.G.P.O., 1903), p. 626 and "figures furnished by the Adjutant General" as his sources.

Sources: For line (1) D. R. Dewey, Financial History of the United States, 12th edition (New York: Longmans, Green and Co., 1939), p. 329; M. S. Kendrick, "A Century and a Half of Federal Expenditures," NBER occasional paper \#48 (New York: NBER, 1955); R. Gallman, unpublished national income estimates (June 1965). (2) A. Bolles, The Financial History of the U.S. from 1861 to 1865 (New York: D. Appleton and Co., 1886); F. A. Shannon, The Organization and Administration of the Union Army, 18611865, Vol. 2 (Cleveland: Arthur H. Clark, Co., 1928), p. 80; M. A. Kriedberg and M. G. Henry, History of Military Mobilization in the United States Army: 1774-1945, Department of Army Pamphlet No. 20-212 (Dept. of the Army, June 1955), pp. 106 and 109. (3) F. A. Shannon, The Organization and Administration of the Union Army, p. 80; M. A. Kriedberg and M. G. Henry, History of Military Mobilization in the United States Army: 1774-1945, pp. 106 and 109. (4) S. Lebergott, Manpower in Economic Growth, (New York: McGraw-Hill, 1964), pp. 510, 528, 539, and 523; J. G. Randall and D. Donald, The Civil War and Reconstruction (Lexington, Massachusetts: D.C. Heath and Co., 1969), p. 531; Historical Statistics, pp. 30, 71 and 738. (5) M. A. Kriedberg and M. G. Henry, History of Military Mobilization in the United States Army: 1774-1945, p. 110; M. S. Kendrick, "A Century and a Half of Federal Expenditures," p. 95.

others in this article are too extensive to be reproduced here, a set of tables (referred to as "Notes" in the text) is available upon request from either author. The total direct cost of the war to the North was about 3.4 billion 1860 dollars. The expenditure by the federal government on soldiers' pay plus bounties and the physical machinery of war accounts for a little more than one half of this total. This expenditure includes costs incurred during the war and demobilization periods minus a hypothetical cost of maintaining defense in the absence of the war. State and local governments also financed the war, paying out substantial bounties to attract quota-filling soldiers. A military draft instituted in 1863 shifted some costs from taxpayers to soldiers and those who furnished substitutes. We have included this item as well.

Approximately 360,000 Union soldiers died due to war-related causes. ${ }^{9}$ The monetary loss from these casualties is computed as the

9 Randall and Donald put total Union deaths at 360,222. See J. G. Randall and D. Donald, The Civil War and Reconstruction (2nd ed. revised; Lexington, Mass.: D.C. Heath and Co., 1969), p. 531. M. A. Kriedberg and M. G. Henry (History 
present value of the foregone income which would have been earned by these men. It comprises less than one-third of the total cost. ${ }^{10}$ We have also added the cost of non-fatal wounds and have subtracted the monetary compensation for risk of death and injury already included in the soldiers' wage bill. All costs are viewed from June 30, 1861 and discounted at six percent to that date.

\section{The Direct Cost of the Civil War to the South}

The direct cost of the war to the South is far more difficult to calculate than that for the North. This partially reflects the chaotic supply efforts of the Confederate government for which individual states as well as private citizens contributed. Records were poorly maintained and deliberately neglected in the many cases where impressment took place. The failure of the Confederate government to pay many of their troops also accounts for incomplete data on costs. ${ }^{11}$

Our computations yield an estimate of this cost, given in Table 2, at 2.89 billion 1860 dollars in 1861 . However, these figures are highly suspect. The expenditures enumerated by the Confederate and state and local governments amount to a trivial half billion dollars in comparison with over 2 billion 1860 dollars spent by the Union. A simple calculation of the expenditures per active soldier for the North and South yields such disparate figures as to cast doubt on the southern estimate. We conclude this figure is biased downward for even

of Military Mobilization in the U.S. Army: 1775-1945, Department of the Army Pamphlet No. 20-212 [Washington, D.C.: Dept. of the Army, June 1955], p. 97) report 359,528 Union deaths, and the U.S. Bureau of the Census (Historical Statistics of the U.S.: Colonial Times to 1957 [Washington, D.C.: U.S.G.P.O., 1960], p. 735 ) puts this figure at 364,511 . The Randall and Donald estimate is used in our analysis.

10 For many purposes the addition of monetary losses due to deaths and injuries would be clearly inappropriate. We have therefore presented these data separately.

11 For descriptions of the coordination of ordnance activities see Frank E. Vandiver, Ploughshares into Swords: Josiah Gorgas and Confederate Ordnance (Austin: University of Texas Press, 1952). Charles W. Ramsdell, Behind the Lines in the Southern Confederacy (Baton Rouge: Louisiana State University Press, 1944) also recounts the well intentioned but ineffective southern efforts at maintaining both military troops and civilians in times of extreme scarcity. On troop pay, Harry $\mathrm{N}$. Scheiber ("The Pay of Confederate Troops and Problems of Demoralization: A Case of Administrative Failure," Civil War History, XV [1969]) states that confederate inability to meet payrolls was encountered early in the war. Bell Wiley, The Life of Johnny Reb (New York: Bobbs-Merrill Co., 1943) also discusses this problem and the steps the rebels took to provide for their families in the absence of military pay. If and when the soldiers were finally paid, it was usually in far lower real terms than had been promised, due to rapid inflation. This partially accounts for the low reported expenditures given in Table 2. 
though northern forces were exceptionally well-equipped it is improbable that the opportunity cost of Confederate manpower and resources per active soldier was forty percent that for Union troops. ${ }^{12}$

One of the major factors biasing downward these expenditures is the seizure of goods which became quite common as the war progressed and inflation mounted. The Confederate army forced sales at lower than current prices and when convenient charged prices quoted during previous transactions. Because inflation was quite rapid, equivalent transactions just a month apart in 1863 differed in price by as much as twenty percent. Goods were also seized without compensation. ${ }^{13}$ In addition, military pay was frequently delayed and paid in much depreciated currency or withheld entirely.

Contemporary descriptions of the extent of seizure and failure to pay troops imply that expenditure data for the Confederacy, especially during the period after 1863 , understate the true cost of the war. We have therefore constructed an adjusted calculation (see Table 3) using the assumption that the opportunity cost of a Confederate soldier equalled that of a Union soldier..$^{14}$ The total labor cost is therefore a multiple of the average size of the Confederate army and the Union wage. ${ }^{15}$ To obtain the cost of capital for the Confederate forces we assume that equipment expenditures per Confederate soldier were one-half those of the Union. The total adjusted figure is not particularly sensitive to changes in this assumption, since labor costs comprise fifty-seven percent of total Union expenditures. Reducing this proportion to one-fourth or increasing it to three-fourths changes our adjusted expenditure estimate by only $\$ 232$ million, or about seven percent of our figure for the total direct cost to the South. In addition, the South, like the North, transferred some war costs to soldiers through the use of a draft, and these costs were added to the direct estimate.

Physical capital destruction accounts for over one-third of the

12 This statistic can be calculated using Tables 1 and 2 and estimates of military manpower given in Table $2, \mathrm{fn}$. g.

13 "[O]n March 26, 1863. .. . Tthe Confederate] Congress approved an act authorizing and regulating the impressment of private property for public use. . . . Before supplies could be impressed, officers had to try to buy them from the owner. . . . Originally, the list prices were only slightly less than the market price, but by the end of the war they had dropped far below." Richard C. Todd, Confederate Finance (Athens: University of Georgia Press, 1954), pp. 165-171.

14 See Table 2, fn. e, for a justification of this assumption.

15 See Table XII of "Notes" for Union army wage rates. 


\section{TABLE 2 \\ DIRECT COST OF THE CIVIL WAR TO THE SOUTHa}

(Thousands, 1860 \$)

\begin{tabular}{llrr}
\hline & Reported & Adjusted $^{\mathrm{h}}$ \\
\hline (1) & Expenditures by the Confederate Government and & & \\
& Auxiliary State and Local Governments & & \\
(2) Additional Costs Due to the Draftc & 20,368 & \\
(3) Decrease in the Value of Physical Capitald & $1,487,241$ & \\
(4) Human Capital Loss: & (a) Killede & 683,939 & \\
& (b) Wounded & 261,231 & \\
(5) Less: Risk Premiums in Soldiers' Wage Billsg & $-178,037$ & \\
(6) Total Direct Cost to the South & $\$ 2,892,709$ & $\$ 3,285,900$ \\
\hline
\end{tabular}

a All values are discounted at 6 percent to June 30, 1861. Lerner's price index with minor adjustments was used. See E. Lerner, "Money, Prices, and Wages in the Confederacy, 1861-1865," in R. Andreano, The Economic Impact of the American Civil War.

b This figure includes loans, treasury notes, taxes, tariffs, reported seizures, and donations. See Table XIII of "Notes."

c Using Randall and Donald's estimates (p. 252) we assume 300,000 men were conscripted and that on average the cost imposed on them was the same as for Union draftees. This may bias our figure downward since a much higher percentage of the Confederate population was drafted.

d Physical capital destruction in the South is measured by the difference between the value of (non-slave) capital in $\mathbf{1 8 6 0}$ and that at the end of the war. The pre-war estimate is based on the true rather than appraised valuation of capital given in the 1860 Census for the eleven states which seceded, with an adjustment to account for the formation of West Virginia. Because of the inadequacy of the 1870 Census with respect to the South, our post-war estimate is based on an 1880 Census valuation of capital. We assume that the rate of growth of capital per person between 1870 and 1880 was the same in the South as it was in the North for Engerman observes that commodity output per capita grew at the same rate in both regions. (See S. Engerman, "The Economic Impact of the Civil War," reprinted in R. Andreano, Economic Impact of the American Civil War.) Our capital destruction figure is highly tentative. But although we are unable to assess the magnitude of all possible biases, it appears that if we have erred it is in the direction of overestimating the true capital loss. This lends further support to our conclusion in the latter part of the paper that the direct estimate is less than the indirect one. See "A Note on Physical Destruction in the South" in "Notes."

e We accept Randall and Donald's estimate of 258,000 Confederate deaths (p. 531) and assume the cost per man to be equal in the North and South. This is justified on the grounds that free per capita income in the South was approximately equal to that in the North in 1860.

$f$ We assume here, due to a lack of southern statistics, that the ratio of dead to wounded was identical in the North as in the South and apply the same logic as in Table 1, fn. f.

$\mathrm{g}$ This figure is based on the same alternative wage data used for the North in Table 1. We have, following Boatner, based the relative average strength of Confederate versus Union forces at $(1,082,119 / 1,556,678)$ but use the absolute figures of Kendrick "A Century and a Half" for the Union to get the Confederate troop numbers. (See Table 1, fn. g.) As in the northern figures we have not attempted to include civilian personnel which Van Riper and Scheiber estimate at 70,000 at the height of operations.

h See text and Table 3 for a discussion of the adjusted figure. 
Sources: For line (1): R. C. Todd, Confederate Finance (Athens: University of Georgia Press, 1954). (2): J. G. Randall and D. Donald, The Civil War and Reconstruction. (3): 1870 Federal Census: Industry and Wealth; $1880 \mathrm{Fed}$ eral Census: Valuation, Taxation and Public Indebtedness. (4): J. G. Randall and D. Donald, The Civil War and Reconstruction. (5): M. M. Boatner, The Civil War Dictionary (New York: David McKay Co., 1959), pp. 602-603.

adjusted direct cost of the war. We have arrived at this figure by subtracting the discounted and deflated value of physical capital (excluding slaves) at the end of the war from that at the beginning. The procedure used is partially described in Table 2 , note $d$, and the final estimate should be considered tentative and probably biased upward.

\section{THE INDIRECT COSTS OF THE CIVIL WAR}

\section{General Method}

The direct computation of the cost of the war is obviously deficient in several respects. It does not fully account for all costs, and furthermore it does not allow for possible benefits to accrue either to the North or more remotely to the entire economy from the shifting of political power. Therefore, we have devised an indirect method of estimating this statistic which incorporates all possible costs and benefits to wartime citizens as well as those to future generations.

This indirect estimate is disaggregated by cost to Union versus Confederate citizens and computed in two ways depending on the definition of a citizen. One estimate defines citizens as all residents, that is it includes immigrants who entered the U.S. after the war began. The other computes the cost to only those living in the U.S. at the outbreak of the conflict and to their descendants.

The general method used is to create a hypothetical economy which did not fight the war. Although various assumptions concerning the growth of per capita consumption are made, the basic supposition is that in the absence of war the economy would have grown at its pre-war rate. ${ }^{16}$ For example, the hypothetical southern

16 The basic assumption chosen is, of course, one of many which could be applied to such a hypothetical warless economy. Nonetheless, there is some evidence to support our choice. George Rogers Taylor concluded in "The National Economy Before and After the Civil War," that "the economy had developed a tremendous thrust during the 1840's and 1850's, a momentum the Civil War may have temporarily retarded or accelerated but could not, or at least did not, fundamentally affect." See D. T. Gilchrist and W. D. Lewis, editors, Economic Change in the Civil War Era 


\section{TABLE 3}

ADJUSTED EXPENDITURE ESTIMATE FOR THE CONFEDERACY (Thousands, $1860 \$$ in 1861)

\begin{tabular}{llrr}
\hline & & Union & Confederacy (adjusted) \\
\hline (1) & Wage Billa & $\mathbf{7 8 7 , 4 0 3 . 7}$ & $\mathbf{5 4 7 , 3 6 0 . 8}$ \\
(2) & Capital Expenditures & \\
(3) & Total Expenditures During the Warc & $1,334,387.3$ & $463,797.2$ \\
\hline
\end{tabular}

a The Union wage bill was calculated from regular army pay plus bounties for Union soldiers. See Table XII of "Notes." We assume that wages were paid from April 1861 to April 1865 and use Kendrick's troop figures for the North. We compute a per soldier wage bill for the North and then apply it to the South. See Table 2, fn. $g$, for our method of computing Confederate troop strength.

b Rows (3) - (1) for Union. See text for discussion of Confederate figure.

c Total Union expenditures equal Table 1 , line $(1)+$ line (2) $-\$ 170$ million, the cost of demobilization. See Table IV of "Notes." The Confederate total expenditure figure is line (1) + line (2).

Sources: See above and text.

economy is assumed to have experienced growth in its per capita consumption at the average annual rate actually attained during the period 1839 to 1859. Additional assumptions, discussed below, are made for the North. The discounted difference between the two consumption streams, the hypothetical minus the actual values, is our indirect estimate of the cost of the Civil War. ${ }^{17}$

(Greenville, Del.: Eleutherian Mills-Hagley Foundation, 1965), p. 22. In summarizing this conference volume Harold F. Williamson noted that with the exception of commercial banking and possibly government-business relations, "principal speakers and critics generally agreed that the Civil War had relatively little or no effect on the particular institutions they were asked to discuss" (p. 172).

17 The indirect cost of the war can also be represented graphically using a production possibilities frontier. We again draw the axes in terms of present and future guns and butter. If the only effect of the war were to increase the output of guns, from $O A$ to $O B$, and reduce that for butter, from $O D$ to $O C$, then the direct and indirect measures would be almost identical. We could represent the indirect cost as CD on the butter axis, that is the foregone consumption due to the war. But if the war involved factors such as political instability, commercial disruption, and

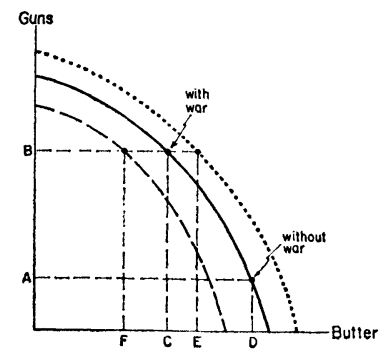

capital destruction, the production possibilities frontier would shift inward, say to the dashed curve in the diagram, and the cost would increase by FC. The direct estimate picks up only part of this additional cost. Our indirect computation should incorporate all foregone consumption. 
We must stress that consumption, not income, is the relevant measure for the cost of a war. Even though measured income may not decrease during a war (it may even increase), consumption could fall dramatically. Therefore, the cost of a war may be positive although income remains constant. Furthermore any investment which is destroyed or created is evaluated in our indirect measure in terms of the consumption it inhibits or eventually generates.

\section{The Indirect Costs of the War to the North (excluding foregone} consumption of those killed)

The indirect cost of the war to the North is the present value in 1861 of the decrease in consumption which resulted from the war. It can be represented in general terms as the following summation:

$$
\text { Indirect Cost }=\sum_{t=1861}^{1909} \frac{C_{h t}-C_{a t}}{(1+i)^{(t-1861)}}
$$

where $\mathbf{C}_{\mathrm{ht}}$ is hypothetical consumption at time $t, \mathbf{C}_{\mathrm{at}}$ is actual consumption at time $t$, and $i$ is the discount rate.

The basic assumption employed for the North is that per capita consumption would have expanded at a constant rate after 1860 such that hypothetical consumption was equal to actual consumption by 1879. It is assumed, therefore, that the more rapid rate observed in the post-bellum period was a "catching up" process and would not have existed in the absence of the war. We feel this is a reasonable assumption because 1879 is the date for which observed income would equal hypothetical income, had the warless economy experienced per capita income growth at the realized 1839 to 1859 rate, 1.56 percent per year. We are implicitly assuming that once income caught up, the war exerted no influence on savings rates. ${ }^{18}$ Therefore, per capita consumption as well as per capita income are equal in both the actual and hypothetical North in 1879. This also

Another possibility to consider is an outward shift in the production possibilities frontier due in some way to the outcome of the war. We depict the situation in the North if there are benefits which accrue to the Union, as implied by the Beards and Hacker. The war cost the Union CD in foregone butter, but if CE of this commodity is returned as the victor's prize, only ED remains as the net indirect cost. If the production possibilities frontier shifts out sufficiently, $C E$ can be greater than $C D$, implying that net benefits could have accrued to the citizens of the triumphant North.

18 For a discussion of the change in post-bellum savings rates and its possible sources see J. G. Williamson, "Watersheds and Turning Points: Conjectures on the Long Term Impact of Civil War Financing," JournaL of Economic Hrstory, XXXIV (September 1974), 636-661. 
implies that in terms of foregone consumption the North experienced no further war costs after 1879. We have incorporated business fluctuations by assuming that deviations from the trend rate of growth in per capita consumption experienced after the war would also have occurred in the hypothetical economy. Alternative assumptions for the hypothetical consumption streams are considered below, but we feel that those outlined above are the most plausible.

The indirect war cost is computed separately for two groups, "natives," and all U.S. residents. The cost to natives is the foregone consumption experienced by those alive in 1861 and their descendants. Assuming that persons alive in 1861 discounted their children's consumption at the same rate at which they discounted their own, this estimate can be compared to the cost of any proposals which were alternatives to war.

The second method, the cost to all U.S. residents, adds to the above estimate the foregone consumption of all immigrants who entered after the conflict began. This estimate will be compared to the direct cost results to shed light on many of the historical questions raised in the above introduction.

Table 4 lists the actual and the hypothetical consumption values in 1860 dollars for both the native and total populations. The discounted value of the difference in the two streams is 4.284 billion 1860 dollars in 1861 for natives only, and 4.515 billion for the total population in the North. ${ }^{19}$ The population and consumption data underlying our figures are included in the Appendix.

The Indirect Cost of the War to the South (excluding foregone consumption of those killed)

The indirect cost of the war to the South was computed in a similar fashion as that for the North, although a slightly different assumption for the hypothetical consumption stream was used. The South did not experience as rapid a "catching up" process as did the North. Indeed the low southern income figures for the post-bellum period have been a perennial puzzle to economic historians. Had per capita income continued to expand in the South at its realized 1839 to 1859 rate, 1.30 percent per year, hypothetical income would have remained higher than the actual values until as late as 1909.

19 This assumes a 6 percent discount rate, and we present results using alternative rates below. These additional computations indicate that our quantitative results are not very sensitive to the discount value chosen. 
TABLE 4

THE INDIRECT COST OF THE WAR TO THE NORTH

(excluding foregone consumption of those killed)

\begin{tabular}{|c|c|c|c|c|}
\hline \multirow[b]{2}{*}{ Year } & $\begin{array}{l}\text { (1) } P a \\
\text { Natives }\end{array}$ & $\begin{array}{l}\text { Consumption } \\
\text { (2) } \\
\text { nsumption }\end{array}$ & $\begin{array}{l}\text { Northa } \\
\text { (3) } \\
\text { All Res }\end{array}$ & $\begin{array}{c}(4) \\
\text { Consumption }\end{array}$ \\
\hline & Actual & $\begin{array}{l}\text { billions) } \\
\text { Hypothetical }\end{array}$ & ${ }^{(1}{ }^{(1}$ & $\begin{array}{l}\text { billions) } \\
\text { Hypothetical }\end{array}$ \\
\hline 1861 & 3.0441 & 3.1609 & 3.0441 & 3.1609 \\
\hline 1862 & 3.0334 & 3.2701 & 3.0450 & 3.2826 \\
\hline 1863 & 3.0106 & 3.3698 & 3.0439 & 3.4071 \\
\hline 1864 & 2.9845 & 3.4686 & 3.0409 & 3.5341 \\
\hline 1865 & 2.9513 & 3.5614 & 3.0362 & 3.6639 \\
\hline 1869 & 3.4397 & 3.9337 & 3.6806 & 4.2092 \\
\hline 1874 & 4.0229 & 4.3021 & 4.4797 & 4.7906 \\
\hline 1879 & 5.1908 & 5.1908 & 6.0201 & 6.0201 \\
\hline 1884 & 6.1739 & 6.1739 & 7.5042 & 7.5042 \\
\hline 1889 & 6.4868 & 6.4868 & 8.2628 & 8.2628 \\
\hline 1894 & 6.6277 & 6.6277 & 8.7288 & 8.7288 \\
\hline 1899 & 8.4953 & 8.4953 & 11.5575 & 11.5575 \\
\hline 1904 & 9.6173 & 9.6173 & 13.6840 & 13.6840 \\
\hline 1909 & 11.1590 & 11.1590 & 16.6227 & 16.6227 \\
\hline
\end{tabular}

Part B. Indirect Cost to the North

(excluding foregone consumption of those killed) ${ }^{b}$

Total (1860 \$ in 1861) Per Capita Cost (billions) in 1861 (1860\$)

\begin{tabular}{llll}
\hline (1) Cost to native population & 4.2844 & 183 \\
(2) Cost to total population & 4.5149 &
\end{tabular}

a See Table 11, "Population Statistics for the South and North, 1861 to 1910," Table 12, "Actual Per Capita Consumption," and Table 13, "Hypothetical Per Capita Consumption," all in the Appendix, for derivation of these figures. It should be noted that our 'actual' figures for 1861 to 1865 are based on a particular set of assumptions. We have therefore computed alternative measures of both actual and hypothetical consumption. These are presented in Table 8.

b A 6 percent interest rate has been used to discount to 1861 the differences between (1) and (2), and (3) and (4) of Part A.

Sources: See above.

Therefore per capita consumption in the hypothetical, warless South is assumed to grow at the realized 1839 to 1859 rate until 1909.

The indirect cost for the South is also computed for the two groups defined in the northern case, and consumption for the hypothetical and actual South is given in Table 5 with supporting data in the Appendix. The indirect cost in 1860 dollars in 1861 is 9.335 billion for natives and 8.970 billion for the total population.

In interpreting the indirect cost estimate for the South it should be noted that it encompasses not merely the actual war costs but also the effects of emancipation and reconstruction. Therefore it 
TABLE 5

THE INDIRECT COST OF THE WAR TO THE SOUTH

(excluding foregone consumption of those killed)

\begin{tabular}{|c|c|c|c|c|}
\hline \multirow[b]{2}{*}{ Year } & $\begin{array}{l}(1) \\
N a t\end{array}$ & $\begin{array}{c}\text { Consumption } \\
(2) \\
\text { sumption }\end{array}$ & $\begin{array}{l}\text { Southa } \\
\text { (3) } \\
\text { All Re }\end{array}$ & $\begin{array}{c}(4) \\
\text { Consumption }\end{array}$ \\
\hline & Actual & $\begin{array}{l}\text { illions) } \\
\text { Hypothetical }\end{array}$ & Actual & $\begin{array}{l}\text { billions) } \\
\text { Hypothetical }\end{array}$ \\
\hline 1861 & .6766 & .7848 & .6766 & .7848 \\
\hline 1862 & .6043 & .8133 & .6043 & .8133 \\
\hline 1863 & .5396 & .8423 & .5396 & .8423 \\
\hline 1864 & .4814 & .8717 & .4814 & .8717 \\
\hline 1865 & .4292 & .9017 & .4292 & .9017 \\
\hline 1869 & .5123 & 1.0268 & .5123 & 1.0268 \\
\hline 1874 & .6259 & 1.1826 & 6075 & 1.1478 \\
\hline 1879 & .8434 & 1.5023 & .7937 & 1.4139 \\
\hline 1884 & 1.0348 & 1.8003 & .9698 & 1.6873 \\
\hline 1889 & 1.1174 & 1.8986 & 1.0434 & 1.7729 \\
\hline 1894 & 1.1920 & 1.9781 & 1.1036 & 1.8314 \\
\hline 1899 & 1.5885 & 2.5745 & 1.4642 & 2.3729 \\
\hline 1904 & 1.9809 & 3.1353 & 1.8231 & 2.8856 \\
\hline 1909 & 2.5336 & 3.9164 & 2.3226 & 3.5903 \\
\hline
\end{tabular}

Part B. Indirect Cost to the South

(excluding foregone consumption of those killed) $\mathbf{b}$

Total (1860 \$ in 1861)

Per Capita Cost (billions) in 1861 (1860 \$)

(1) Cost to native population

$9.3348^{\mathrm{c}}$

(2) Cost to total population

$8.9695^{\mathrm{c}}$

1042

a See fn. a, Table 4.

b See fn. b, Table 4 .

c The native population estimates for the South exceed the total population figures after 1869 because of outmigration (see Table 11). Since average per capita costs in the South are applied to natives whether or not they migrated, the indirect cost estimate for natives exceeds that for the total southern population. This also explains why Table 7 shows a slightly higher cost to natives than to all residents.

Sources: See above.

includes any change in consumption due to a lowering in work effort by freed slaves. To the extent that freedmen withdrew a portion of their labor after emancipation in favor of increased leisure our estimate will be increased. In addition, any scale economies which could be reaped only from a slave plantation economy will also be included. ${ }^{20}$

20 See R. W. Fogel and S. L. Engerman, Time on the Cross: The Economics of American Negro Slavery (Boston: Little Brown and Co., 1974), Chapter 6 for a discussion of scale economies. Other war and emancipation related costs are also included. For example, the value of cotton burned during the war is implicitly incorporated in the indirect measure. Although there is no estimate of the quantity actually destroyed, most accounts report it was substantial. See C. Eaton, A History of the Southern Confederacy (New York: Macmillan Co., 1954), p. 241. 
Although we cannot completely disassociate the effects of the Civil War from those of emancipation, we have attempted to estimate the impact of a decrease in work effort by freedmen. Following R. Ransom and R. Sutch, we have computed the decline in consumption due to increased leisure at $\$ 1.96$ billion (1860 dollars in 1861). This uses Ransom and Sutch's estimate of a thirty-two percent decline in work effort for every year following emancipation. We have applied this number as an upper bound and conclude that this one factor does not serve to explain the large change in consumption in the post-bellum South. Indeed it accounts for only one-third of the unexplained portion (indirect minus direct) of the total indirect measure. ${ }^{21}$

21 R. Ransom and R. Sutch (What Was Freedom Worth? [forthcoming], Chapter 3, "The Myth of the Devastated South") estimate that total male equivalent work hours supplied to agriculture per capita declined by about 32 percent due to emancipation (p. 13). The average wage rate of farm labor in the states which seceded was $\$ 182.08$ (current) in 1870. See S. Lebergott, Manpower in Economic Growth (New York: McGraw-Hill, 1964), p. 539 for monthly earnings, and H. T. Eldridge and D. S. Thomas, Demographic Analysis and Interrelations, Population Redistribution and Economic Growth: United States, 1870-1950, Vol. 1 (Philadelphia: American Philosophical Society, 1964), pp. 609-621 for the farm labor force used as weights in each state. Wage rates are augmented by one third to allow for board. The 1860 slave population in the states which seceded $(3,521,110)$ is assumed to increase between 1860 and 1870 at the rate given for all blacks in the South, implying a freedman population of 4,239,461 in 1870. Applying Ransom and Sutch's cohort shares (p. 13), multiplying by the fraction of each group engaged in agriculture, and adjusting for the lower productivity and shorter work year of women and children yields $1,704,800$ male-equivalent workers in 1870 . This group earned by our calculations 213,836 thousand 1860 dollars but would have received 47.3 percent more at the higher 1860 work levels. This addition represents 18.97 percent of actual 1870 southern consumption. Therefore, the higher pre-war work effort increases measured consumption in 1870 by 18.97 percent. Applying this same proportion to actual southern consumption in every year following the Civil War yields a total present value for the increased leisure of former slaves of $\$ 1.96$ billions of 1860 dollars in 1861.

We believe this figure is an upper bound because the Ransom and Sutch estimate of the decline in work effort appears quite high. For example, in a recent paper $\mathbf{R}$. Keith Aufhauser suggests that work effort in Louisiana by ex-slaves and poor whites together rose after the war. Therefore, even if the work effort of ex-slaves fell, it may have been offset by an increase in work by the whites. See R. K. Aufhauser, "The Effects of Emancipation in Louisiana and Jamaica," unpublished manuscript (Queen's University, N.Y.). In addition, although work effort may have dropped substantially just after emancipation, it probably rose in subsequent decades.

Gavin Wright, "Cotton Competition and the Post-Bellum Recovery of the American South," JourNal of Economic History, XXXIV (September 1974), 610-635, discounts the importance of the decline in work effort and the loss of scale economies, relative to the issue of the growth in demand for cotton. He states that "productive efficiency per se may be less important for the study of southern income growth than the position of the South in the world economy" (p. 635). If the demand for cotton rose at a slower rate after than before the war, some of our indirect measure would be capturing this change, which is probably not due to the war. 
TABLE 6

INDIRECT COST DUE TO LOSS OF LIFE

$1860 \$$ in 1861 (billions)

(1) Cost to Northa

.7106

(2) Cost to South

.5090

a We arrive at these figures by multiplying hypothetical per capita consumption in each year by the number of war related deaths for that year, and then discounting to 1861. We apply hypothetical per capita consumption in the North to both Union and Confederate dead since the average per capita income of free southerners was approximately equal to that of northerners in 1861 .

Sources: See above.

The indirect estimates have so far ignored some of the losses stemming from war deaths. ${ }^{22}$ Because the indirect measure is construed as foregone consumption, war wounds which decreased earning ability have been implicitly included. In addition, losses to those alive due to the deaths of specific, complementary factors have also been accounted. Therefore the only cost which the indirect estimate has not considered is the decline in consumption of those who died as a result of the war. To compute this cost we have included in the hypothetical North and South those persons who were killed during the war by extending their lives to what they would have been in the absence of the war. ${ }^{23}$ This additional cost due to war-related deaths is enumerated in Table 6.

Table 7 ties together all the indirect estimates presented in this section. The total indirect cost represents all net consumption lost because of the Civil War. Consumption declined globally by 14.704 billion 1860 dollars, in 1861, with the South bearing about sixty-five percent of the war's burden.

\section{Alternative Indirect Estimates}

Our estimate of the indirect cost of the Civil War to the North and the South depends crucially on assumptions concerning the rate at which the economy would have grown in the absence of conflict and the rate at which actual consumption changed during the war. In order to ascertain the sensitivity of our results to the particular

22 We have separated costs due to war deaths from other components because this is an item which can be computed in several ways depending on one's point of view. In addition, there are many uses of these statistics for which an estimate including war deaths would be inappropriate.

23 Note that we have excluded children who would have been born to men whose deaths were due to the war. 
TABLE 7

TOTAL INDIRECT COST OF THE CIVIL WAR

\begin{tabular}{llcc}
\hline & & \multicolumn{2}{c}{$1860 \$$ in 1861 (billions) } \\
& & Natives & All Residents \\
\hline (1) & North & 4.9950 & 5.2255 \\
(2) & South & 9.8438 & 9.4785 \\
(3) & Total & 14.8388 & 14.7040 \\
\hline
\end{tabular}

a See footnote c, Table 5 .

Sources: Tables 4, 5 and 6.

assumptions chosen we have reestimated them on the basis of alternative hypotheses.

Actual per capita consumption under the alternative assumption is constructed to decline at a constant rate throughout the period 1861 to 1869 , rather than to decline from 1861 to 1865 and then rise from 1865 to 1869 at the realized 1869 to 1879 rate. The alternative assumption for the hypothetical economy, which finds its roots in the works of Hacker and the Beards, is that in the absence of war the northern economy would have grown at a rate slower than that achieved during the pre-war period. This is also applied to the South in light of the presumption of many that southern growth would have declined even without the war. ${ }^{24}$ We have chosen the rather low rate of one percent as our alternative rate of change in hypothetical per capita consumption from 1861 to 1879 and apply the hypothetical rate used above for the period after 1879 .

We present three cases using these alternative assumptions. The first uses the original actual stream and the alternative hypothetical stream. The second applies the alternative actual stream and the original hypothetical stream and the third uses both alternative streams.

The indirect cost estimates given in Table 8 for the South are fairly insensitive to changes in our assumptions about the hypothetical and actual growth rates, and for the set of assumptions (Case 3 ) which minimizes the cost of the war, the indirect measure declines by only fourteen percent. That for the North is somewhat more sensitive to changes in our assumptions, and the set (Case 3) most unfavorable to our conclusions results in only half the previ-

24 Most of these arguments concern the detrimental effects of slavery on the southern economy. For an excellent summary of this literature see R. W. Fogel and S. L. Engerman, "The Economics of Slavery," in their The Reinterpretation of American Economic History (New York: Harper and Row, 1972). 
TABLE 8

INDIRECT COST OF THE CIVIL WAR UNDER

ALTERNATIVE ASSUMPTIONSa

(billions of $1860 \$$ in 1861 )

\begin{tabular}{|c|c|c|c|}
\hline & Case $1^{\mathrm{b}}$ & Case $2^{\mathrm{c}}$ & Case $3^{\mathrm{d}}$ \\
\hline $\begin{array}{l}\text { North: } \\
\text { Cost, excluding foregone consumption } \\
\text { of those killed } \\
\text { Foregone consumption of those killed } \\
\text { Total }\end{array}$ & $\begin{array}{r}2.9116 \\
.6997 \\
3.6113\end{array}$ & $\begin{array}{r}3.1745 \\
.7106 \\
3.8851\end{array}$ & $\begin{array}{r}1.5712 \\
.6997 \\
2.2709\end{array}$ \\
\hline $\begin{array}{l}\text { South: } \\
\text { Cost, excluding foregone consumption } \\
\text { of those killed } \\
\text { Foregone consumption of those killed } \\
\text { Total }\end{array}$ & $\begin{array}{r}8.0203 \\
.5011 \\
8.5214\end{array}$ & $\begin{array}{r}8.2420 \\
.5089 \\
8.7509\end{array}$ & $\begin{array}{r}7.2928 \\
.5011 \\
7.7939\end{array}$ \\
\hline
\end{tabular}

a A 6 percent discount rate is used and the cost is computed for all residents.

b Actual stream unchanged; new hypothetical stream. See Appendix Table 14.

c Hypothetical stream unchanged; new actual stream. See Appendix Table 14.

d New actual and new hypothetical streams. See Appendix Table 14.

Sources: See above.

ously measured indirect cost. Although this may appear to be a large change, it does not drastically affect our qualitative results.

We have also constructed additional estimates using alternative rates of return. Although we have based our six percent discount rate on an average of rates of return earned during the period 1861 to $1909,{ }^{25}$ we realize that a consideration of other discount rates is useful. The estimates in Table 9 show the sensitivity of our results to discount rates close to six (viz. five and seven) and also to a zero discount rate. Our quantitative results are not much affected by the first two, while the latter yields very high indirect costs for the South.

\section{A FEW IMPLICATIONS OF THE DIRECT AND INDIRECT COSTS OF THE CIVIL WAR}

\section{The Cost of the War in Per Capita Terms}

One useful way of expressing the cost of the Civil War is as the percentage of hypothetical consumption per capita foregone because of the war. The amount of foregone per capita consumption and this value as a percent of hypothetical consumption, 1861 to 1909, are given in Table 10. Because we have assumed that the 
TABLE 9

COST OF THE CIVIL WAR USING ALTERNATIVE RATES OF DISCOUNT ( $1860 \$$, billions)

\begin{tabular}{lccccrrr}
\hline & \multicolumn{3}{c}{ North } & & 3 & South $\mathrm{a}$ \\
\cline { 2 - 5 } \cline { 6 - 7 } & $r=.07 \mathrm{~b}$ & $r=.05$ & $r=0$ & & $r=.07$ & $r=.05$ & $r=0$ \\
\hline Direct Cost & 3.1599 & 3.6135 & 6.2337 & & 3.1273 & 3.4748 & 5.4127 \\
Indirect Costc & 4.8686 & 5.6309 & 8.9288 & & 8.0736 & 11.3066 & 36.3019 \\
\hline
\end{tabular}

a The direct cost estimate for the South is based on our adjusted Confederate expenditures.

b $r=$ rate at which costs are discounted.

c These costs are for all residents and include the foregone consumption of those killed.

Sources: See text.

North "caught up" by 1879, no costs are experienced by Union citizens after that date. The South, however, did not experience this rapid catching up process, and foregone consumption losses continue into the twentieth century.

Those who remained in the South experienced the greatest losses. In fact as late as 1909 southerners on average consumed roughly thirty percent less than had per capita consumption continued to grow after 1860 at the antebellum rate. These persistent losses in the South are due to a variety of causes among which we cannot distinguish at the present time. There were capital losses, general instability and commercial stoppage. The slow recovery in the South

TABLE 10

PER CAPITA COST OF THE CIVIL WAR: 1861 TO 1909

\begin{tabular}{|c|c|c|c|c|c|c|}
\hline \multirow[b]{2}{*}{ Year } & \multicolumn{2}{|c|}{ Total U.S. } & \multicolumn{2}{|c|}{ North } & \multicolumn{2}{|c|}{ South } \\
\hline & $1860 \$ a$ & \% of P.C.C. & $1860 \$$ & \% of P.C.C. & $1860 \$$ & \% of P.C.C. \\
\hline 1861 & 8.41 & 6.9 & 4.99 & 3.7 & 12.09 & 13.8 \\
\hline 1862 & 13.46 & 10.9 & 11.43 & 8.4 & 22.81 & 25.7 \\
\hline 1863 & 19.58 & 15.7 & 15.29 & 11.1 & 32.32 & 35.9 \\
\hline 1864 & 25.34 & 20.1 & 19.50 & 14.0 & 40.78 & 44.8 \\
\hline 1865 & 30.81 & 24.1 & 24.21 & 17.1 & 48.34 & 52.4 \\
\hline 1869 & 26.71 & 19.9 & 18.56 & 12.6 & 48.67 & 50.1 \\
\hline 1874 & 19.33 & 14.3 & 9.61 & 6.5 & 46.21 & 47.1 \\
\hline 1879 & 12.60 & 8.3 & 0 & 0 & 48.46 & 43.9 \\
\hline 1884 & 12.95 & 7.8 & 0 & 0 & 50.77 & 42.5 \\
\hline 1889 & 12.30 & 7.6 & 0 & 0 & 47.15 & 41.1 \\
\hline 1894 & 10.66 & 6.9 & 0 & 0 & 42.71 & 39.7 \\
\hline 1899 & 12.15 & 6.5 & 0 & 0 & 48.66 & 38.3 \\
\hline 1904 & 12.93 & 6.4 & 0 & 0 & 52.31 & 36.8 \\
\hline 1909 & 14.01 & 6.3 & 0 & 0 & 57.39 & 35.3 \\
\hline
\end{tabular}

a This is a population weighted average of the costs for the North and the South.

b Percent of hypothetical per capita consumption.

Sources: See text. 
may indeed have had much to do with Reconstruction, and it is possible that emancipation lowered measured consumption by preventing the exploitation of scale economies. As pointed out earlier, part of this cost could also be the result of ex-slaves' lowering their work effort in favor of increased leisure and would not necessarily imply a decrease in well being.

\section{DID THE CIVIL WAR ACCELERATE U.S. OR NORTHERN GROWTH?}

Many historians interpret the Civil War as a watershed in American history because they believe it fundamentally changed the U.S. economy to one receptive to industrialization. Two well-known theses concerning the effects of the Civil War on the American economy are those of Charles and Mary Beard and Louis Hacker. The Beards view the termination of the Civil War conflict as beginning the "rise of capitalism." Through a mechanism which they never completely detail, the destruction of agrarianism with Confederate defeat "assured the triumph of business enterprise." Hacker's thesis is similar to that of the Beards, but the engine of industrialism in his model is more precisely specified. Northern victory gave the industrialist-capitalist class, "the instrumentalities of political power" used to pass legislation which enabled "the triumph of American capitalism."26

One interpretation of the Beard-Hacker thesis is that the Civil War enabled greater growth rates than would have been achieved in the U.S. without the war. This implies that some of the costs of the war were offset by benefits from industrialization. Even though wartime destruction reduced our capacity to produce consumption goods, the war's political consequences may have produced a higher rate of growth of per capita consumption. Therefore it is possible that the war conferred net benefits on either the whole U.S. or at least on the northern sector.

Many economists and historians have challenged these views, using data on industrialization gathered since the Beard and Hacker volumes were written. They have, in general, found that the era following the Civil War was not a break with the past in terms of economic activity. For example, Cochran reports that changes in value added for the period 1839 to 1859 are similar to those for 1869 to 1889 , and that the war had little lasting impact on the production

26 Hacker, The Triumph of American Capitalism, p. 251. 
of pig iron, bituminous coal, and railroad track. Engerman reiterates the Cochran position with further data and shows that total commodity output grew at 4.6 percent from 1840 to 1860 and at 4.4 percent from 1870 to 1900 . In addition, the shift toward manufacturing after the war was merely a continuation of changes already begun before the conflict. ${ }^{27}$ The Civil War for these scholars has not stood up to the test of being a watershed era.

Although it now seems clear that the Civil War did not radically alter the path of American industrialization, the debate on the impact of the war still has not answered the question of whether the war conferred net gains on the North or on the U.S. as a whole. We interpret the Beards and Hacker to imply that many groups in the U.S. benefited on net from the Civil War, and we can partially test this proposition with our direct and indirect cost estimates. ${ }^{28}$

The direct cost statistic measures all war costs except those due to political instability, possible postwar gains stemming directly from the war, and so on. The indirect estimate captures all costs and benefits, for it measures total consumption foregone due to the war. Therefore the difference between the two can be identified as any cost or benefit which was not included in the direct estimate. In particular, the gains from industrialization, á la Hacker and the Beards, would be contained in this difference.

The North experienced $\$ 3.37$ billion in direct costs and $\$ 5.23$ billion using the indirect method. Therefore, $\$ 1.86$ billion was not captured in the direct cost estimate. If the North experienced an increase in consumption due to the war, it had to have been either very minor or much overweighed by unrecorded war destruction and costs. ${ }^{28}$

27 See Cochran, "Did the Civil War Retard Industrialization?" and Engerman, "The Economic Impact of the Civil War," in Andreano, The Economic Impact of the American Civil War.

28 Our reading of the Beards and Hacker is only one of several possible interpretations. For example, they could be implying that the distribution of income, not actual consumption, was changed. But even if this is the correct interpretation, we can test the proposition that the North alone gained at the expense of the South. In addition, although the Beards and Hacker allow for "spillover" effects to other sectors, they may be saying that only northern capitalists gained at the expense of labor. We have not attempted to test this proposition. See Engerman, "The Impact of the American Civil War," on this point.

29 As noted above, this conclusion holds only if we assume that per capita consumption in the North would have continued to grow at close to, or above, the prewar rate in the absence of a war. Using both alternative hypotheses (Case 3, Table 8) changes our results, and we get a $\$ 1.09$ billion ( $\$ 3.366-\$ 2.271)$ gross gain to the 
The difference in the southern direct and indirect measures is even greater and amounts to a staggering $\$ 4.23$ billion. Included in this figure are costs due to the loss of scale economies from the use of slaves in agriculture, capital destruction which was not included in our estimate, and political instabilities during the war and reconstruction periods. ${ }^{30}$

In conclusion, we find no evidence that the Civil War benefited either the North or the whole U.S. even in a gross way. On the contrary, the costs of the war were so wide-ranging and persistent that in spite of thorough investigation the direct measure captures only forty-two percent of these costs for the entire United States. ${ }^{31}$

Claudia D. Goldin, Princeton University Frank D. Lewis, Queen's University, Ontario

North from the war. But since the indirect cost is still positive this possible redistribution was outweighed by other costs resulting from the conflict.

30 We have netted out losses due to a decline in freedman's work effort by subtracting our upper bound figure of $\$ 1.96$ billion.

$31 \$ 6.66$ billion has been accounted for in our direct cost estimate although the indirect estimate yields $(\$ 14.70-\$ 1.96=\$ 12.74)$. We subtract from the indirect measure our estimate for the cost of greater leisure time in the post-bellum South. 
APPENDIX

APPENDIX TABLE 11

POPULATION STATISTICS FOR SOUTH AND NORTH, 1861 TO 1910

(Thousands)

\begin{tabular}{lcccccc}
\hline & $\begin{array}{c}(1) \\
\text { Population }\end{array}$ & $\begin{array}{c}(2) \\
\text { Population } \\
\text { Non-South }\end{array}$ & $\begin{array}{c}(3) \\
\text { Population } \\
\text { South }\end{array}$ & $\begin{array}{c}(4) \\
\text { "Native" } \\
\text { Population } \\
\text { U.S. }\end{array}$ & $\begin{array}{c}(5) \\
\text { "Native" } \\
\text { Population } \\
\text { Non-South }\end{array}$ & $\begin{array}{c}\text { (6) } \\
\text { "Native" } \\
\text { Population } \\
\text { South }\end{array}$ \\
\hline 1861 & 32351 & 23394.8 & 8956.2 & 32351 & 23394.8 & 8956.2 \\
1862 & 33188 & 24025.8 & 9162.2 & 33096 & 23933.8 & 9162.2 \\
1863 & 34026 & 24658.8 & 9367.2 & 33756 & 24388.8 & 9367.2 \\
1864 & 34863 & 25292.4 & 9570.6 & 34394 & 24823.4 & 9570.6 \\
1865 & 35701 & 25927.9 & 9773.1 & 34976 & 25202.9 & 9773.1 \\
1869 & 39051 & 28480.9 & 10570.1 & 37187 & 26616.9 & 10570.1 \\
1874 & 44040 & 32346.9 & 11693.1 & 41096 & 29048.4 & 12047.6 \\
1879 & 49208 & 36410.2 & 12797.8 & 44993 & 31394.7 & 13598.3 \\
1884 & 55379 & 41247.5 & 14131.5 & 49014 & 33935.7 & 15078.3 \\
1889 & 61775 & 46303.0 & 15472.0 & 52919 & 36350.7 & 16568.3 \\
1894 & 68275 & 51234.2 & 17040.8 & 57308 & 38901.8 & 18406.2 \\
1899 & 74799 & 56123.2 & 18675.8 & 61515 & 41253.1 & 20261.9 \\
1904 & 82165 & 61854.0 & 20311.0 & 65541 & 43472.0 & 22069.0 \\
1909 & 90492 & 68403.4 & 22088.6 & 70015 & 45920.1 & 24094.9 \\
\hline 1860 & 31433.3 & 22706.7 & 8726.6 & & & \\
1870 & 39818.4 & 29071.0 & 10747.4 & & & \\
1880 & 50155.8 & 37165.6 & 12990.2 & & & \\
1890 & 62947.7 & 47241.0 & 15706.7 & & & \\
1900 & 75994.6 & 57018.9 & 18975.7 & & & \\
1910 & 91972.3 & 69579.1 & 22393.2 & & & \\
\hline
\end{tabular}

Notes: Column (1): Historical Statistics, p. 7 and 8. Columns (2) and (3): A Federal Census undernumeration of the 1870 southern population data is partially rectified in Historical Statistics, p. 8. Although this gives the reestimated total U.S. population figure, this adjustment is not incorporated in the state totals, (p. 13). Our 1870 southern population is computed by subtracting the 1870 non-South population from the reestimated total population. Column (4): The total U.S. native population is computed by subtracting the net number of immigrants who entered after 1861 from the total population. The children of these immigrants are also subtracted using the assumption that the natural rate of increase of immigrants was equal to that for natives. Columns (5) and (6): It is assumed that all immigrants who entered from 1861 to 1869 went to the North. For the period after 1869 , the ratio of the rate of increase of the native population in the South to the corresponding rate in the North is assumed to equal the ratio of the natural rate of increase in the South to that in the North. See Table XV of "Notes."

Sources: Historical Statistics, p. 7, 8, 12 and 13. Hope T. Eldridge and Dorothy S. Thomas, Demographic Analyses and Interrelations, Population Redistribution and Economic Growth: United States, 1870-1950, Vol. III (Philadelphia: American Philosophical Society, 1964), p. 33. See also Table XV of "Notes" for rates of natural increase in the North and South. 
APPENDIX TABLE 12

ACTUAL PER CAPITA CONSUMPTION $(1860 \$)$

\begin{tabular}{cccc}
\hline Year & $(1)$ & $\begin{array}{c}(2) \\
\text { Non-South }\end{array}$ & $\begin{array}{c}(3) \\
\text { South }\end{array}$ \\
\hline 1860 & U.S. & 133.60 & 86.51 \\
1861 & 120.53 & 130.12 & 75.54 \\
1862 & 115.01 & 126.74 & 65.96 \\
1863 & 109.96 & 123.44 & 57.60 \\
1864 & 105.31 & 120.23 & 50.30 \\
1865 & 101.03 & 117.10 & 43.92 \\
1869 & 97.07 & 129.23 & 48.47 \\
1874 & 107.37 & 138.49 & 51.95 \\
1879 & 115.51 & 165.34 & 62.02 \\
1884 & 138.47 & 181.93 & 68.63 \\
1889 & 153.02 & 178.45 & 67.44 \\
1894 & 150.16 & 170.37 & 64.76 \\
1899 & 144.01 & 205.93 & 78.40 \\
1904 & 174.09 & 221.23 & 89.76 \\
1909 & 188.73 & 243.01 & 105.15 \\
\hline
\end{tabular}

a Per capita consumption in the North and South for the periods 1839 to 1859 and 1869 to 1909 is derived from Gallman's national income figures and from Easterlin's regional income estimates. An adjustment is made to the Easterlin estimate to allow for the difference between the states comprising the South and those in the Confederacy. Eldridge and Thomas in Population Redistribution give state per capita consumption values for 1880, 1900, and 1920. (The District of Columbia, not included in these data, is assigned the Delaware estimate.) Intermediate year values are based on the assumption that the ratio of per capita consumption in the South to that in the U.S. changed at a constant rate. For the period 1839 to 1859 , it is assumed that the southern states which did not secede had the same average per capita consumption as those that did. The 1860 values are based on the assumption that each region grew at the same rate from 1859 to 1860 as it did from 1839 to 1859 . Furthermore, it is assumed that each grew at its 1869 to 1879 rate between 1865 and 1869. For the period 1860 to 1865 we assume that per capita consumption fell at a constant rate in each region.

Sources: R. Easterlin, "Regional Income Trends," reprinted in Fogel and Engerman, The Reinterpretation of American Economic History, pp. 39-40; Eldridge and Thomas, Population Redistribution, Vol. 1, p. 753; Historical Statistics, pp. 12 and 13; Gallman, unpublished national income estimates (June 1965); Engerman, "Economic Impact of the Civil War," reprinted in Fogel and Engerman, The Reinterpretation of American Economic History, p. 372. 
APPENDIX TABLE 13

HYPOTHETICAL PER CAPITA CONSUMPTION $(1860 \$)$

\begin{tabular}{cccr}
\hline Year & U.S. & Non-South & South $^{\mathrm{a}}$ \\
\hline 1861 & 121.97 & 135.11 & 87.63 \\
1862 & 123.42 & 136.63 & 88.77 \\
1863 & 124.89 & 138.17 & 89.92 \\
1864 & 126.37 & 139.73 & 91.08 \\
1865 & 127.88 & 141.31 & 92.26 \\
1869 & 134.08 & 147.79 & 97.14 \\
1874 & 134.84 & 148.10 & 98.16 \\
1879 & 151.07 & 165.34 & 110.48 \\
1884 & 165.97 & 181.93 & 119.40 \\
1889 & 162.46 & 178.45 & 114.59 \\
1894 & 154.67 & 170.37 & 107.47 \\
1899 & 186.24 & 205.93 & 127.06 \\
1904 & 201.66 & 221.23 & 142.07 \\
1909 & 223.37 & 243.01 & 162.54 \\
\hline
\end{tabular}

a Hypothetical per capita consumption in the non-South is assumed to grow at a constant rate from 1860 to the actual 1879 figure, with the following adjustment for deviations from trend values between 1869 and 1879. Let:

$\mathrm{C}_{\mathrm{a}} \mathbf{i}_{(\mathrm{h})}=$ actual (hypothetical) per capita consumption in year $\mathbf{i}$

$r_{a(h)}=$ trend rate of growth of actual (hypothetical) per capita consumption Setting $i=0$ in the base year, we adjust for deviations from trend by assuming:

$$
\frac{C_{a} t}{C_{a}{ }^{0}\left(1+r_{a}\right) t}=\frac{C_{h} t}{C_{h}^{0}\left(1+r_{h}\right) t} \text {. }
$$

Actual and hypothetical per capita consumption are identical after 1879.

b Hypothetical per capita consumption in the South is assumed to grow at the $\mathbf{1 8 3 9}$ to 1859 rate, with the above adjustment for deviations from trend values in the periods 1869 to 1879 and 1879 to 1909 . The period 1869 to 1909 is divided into two parts because the acceleration in the rate of growth which occurred between 1869 and 1879 is assumed to have been a result of the war. Therefore, our hypothetical growth path is not constructed to exhibit this deviation from the 1869 to 1909 trend rate of growth.

Sources: See above. 
APPENDIX TABLE 14

ACTUAL AND HYPOTHETICAL PER CAPITA CONSUMPTION UNDER ALTERNATIVE ASSUMPTIONS ${ }^{a}$

$(1860 \$)$

\begin{tabular}{|c|c|c|c|c|}
\hline \multirow[b]{2}{*}{ Year } & (1) & North & \multicolumn{2}{|c|}{ South } \\
\hline & Actual & Hypothetical & Actual & Hypothetical \\
\hline 1861 & 133.11 & 134.94 & 81.12 & 87.38 \\
\hline 1862 & 132.62 & 136.29 & 76.06 & 88.25 \\
\hline 1863 & 132.13 & 137.65 & 71.32 & 89.13 \\
\hline 1864 & 131.64 & 139.02 & 66.87 & 90.02 \\
\hline 1865 & 131.15 & 140.41 & 62.70 & 90.92 \\
\hline 1869 & 129.23 & 146.12 & 48.47 & 94.61 \\
\hline 1874 & 138.49 & 145.50 & 51.95 & 89.64 \\
\hline 1879 & 165.34 & 161.40 & 62.02 & 104.51 \\
\hline 1884 & 181.93 & 177.59 & 68.63 & 112.95 \\
\hline 1889 & 178.45 & 174.20 & 67.44 & 108.40 \\
\hline 1894 & 170.37 & 166.31 & 64.76 & 101.66 \\
\hline 1899 & 205.93 & 201.02 & 78.40 & 120.19 \\
\hline 1904 & 221.23 & 215.96 & 89.76 & 134.39 \\
\hline 1909 & 243.01 & 237.22 & 105.15 & 153.76 \\
\hline
\end{tabular}

a We have computed the indirect cost of the war using both an alternative hypothetical consumption stream and an alternative "actual" consumption stream to test the sensitivity of our initial results. The latter change applies to the period 1861 to 1869 for which data on consumption are not available. Although the "actual" consumption stream which we use for 1861 to 1869 (see Table 12) seems the most reasonable to us, we have tested the sensitivity of our results by assuming that per capita consumption declined at a constant rate throughout the Civil War decade. We assume in the new hypothetical case that per capita consumption would have grown from 1861 to 1879 at only 1 percent per year. After 1879, we apply the same rate of growth exhibited by the hypothetical consumption stream in Table 13.

Source: See above. 